\title{
ECONOMIC HISTORY ASSOCIATION ANNUAL MEETING
}

The fortieth annual meeting of the Economic History Association will take place at the Park Plaza Hotel, Boston, Mass., September 11-13, 1980. The preliminary program is as follows:

1) The Effect of Technological Change on Work and Work Processes

Elyce J. Rotella, Tufts University and San Diego State University, "The Transformation of the American Office: Mechanization and the Organization of Work"

William H. Mulligan, Jr., Eleutherian Mills-Hagley Foundation, "Mechanization and Work in the American Shoe Industry: The Shoemakers of Lynn, Massachusetts, 1852-1883"

Leonard Carlson, Emory University, "Labor Supply, the Acquisition of Skills, and the Location of Southern Textile Mills, 1870-1900"

2) Inequality and Income Transfers since the Industrial Revolution

Jeffrey G. Williamson, University of Wisconsin, "Inequality and Capitalism: Early Findings from Nineteenth-Century Britain"

Jeremy Atack, University of Illinois, and Fred Bateman, Indiana University, "Egalitarianism and Inequality, a Case Study: The Rural North in 1860"

John Joseph Wallis and Daniel K. Benjamin, University of Washington, "Relief Policies and Unemployment in the Great Depression"

3) Constraints on Economic Growth

Elias H. Tuma, University of California, Davis, "Why Problems Do Not Go Away"

William H. Lazonick, Harvard University, "Industrial Organization and Economic Growth: U.S. and British Cotton Textiles, 1870-1940"

David Galenson, The University of Chicago and California Institute of Technology, "The Indenture System and the Development of Black Slavery in British America"

4) Bureaucrats and Businesspeople: Organizational Change in the Private and Public Sectors Hugh Rockoff, Rutgers College, "The Response of the Giant Corporations to Wage and Price Controls in World War II"

Louis P. Cain, Loyola University of Chicago, and George Neumann, The University of Chicago, "Planning for Peace: The Surplus Property Act of 1944"

Frank Tipton, University of Sydney, "Government as an Agent of Change: A Skeptical View of Bureaucratic Policies and Economic Development in Germany and Japan"

Gary Libecap, Texas A \& M University, "Bureaucratic Behavior and the Assignment of Grazing Rights to Federal Lands"

5) The Economic History of Pre-Industrial Societies

Andrew B. Appleby, San Diego State University, "The Problem of Subsistence in Early Modern Europe"

Ann Harper-Fender, Gettysburg College, "Discouraging Use of a Common Resource: The Crees of Saskatchewan"

Peter Toumanoff, Marquette University, "The Development of the Peasant Commune in Russia"

Marilyn Gerriets, Wilfrid Laurier University, "The Organization Exchange: The Craftsman in Early Christian Ireland according to the Ancient Laws of Ireland"

6) Law and Economic Growth

Harry N. Scheiber, University of California, San Diego, "Regulation, Property Rights, and Definition of 'The Market': Law and the American Economy"

Terry Anderson and P. J. Hill, Montana State University, "Economic Growth in a Transfer Society: The United States' Experience" 